\title{
A impossibilidade da morte na literatura: Lygia Fagundes Telles e Maurice Blanchot
}

\author{
The impossibility of death in literature: \\ Lygia Fagundes Telles and Maurice Blanchot \\ La imposibilidad de la muerte en la literatura: \\ Lygia Fagundes Telles y Maurice Blanchot
}

Davi Andrade Pimentel ${ }^{\star}$

\section{Resumo}

A partir do conto "Natal na barca", de Lygia Fagundes Telles, este artigo analisa a perspectiva da impossibilidade da morte em três contos ("As formigas", "Anão de jardim" e "Venha ver o pôr-do-sol") e em dois romances (Ciranda de pedra e As meninas) da autora. Em diálogo com os textos de Lygia, o escritor francês Maurice Blanchot nos oferece a base teórica deste artigo, uma vez que a ideia da impossibilidade da morte na literatura é profundamente trabalhada em seus livros ensaísticos, tais como, O espaço literário e A parte do fogo.

Palavras-chave: morte, Lygia Fagundes Telles, Maurice Blanchot.

\section{Abstract}

Based on the short story "Natal na barca" by Lygia Fagundes Telles, this article analyzes the perspective of the impossibility of death in three short stories ("As formigas", "Anão de jardim" and "Venha ver o pôr-do-sol") as well as in two novels (Ciranda de Pedra and As meninas) by the same author. In dialogue with the texts of Lygia, the French author Maurice Blanchot offers us a theoretical basis for this article, since his ideas of the impossibility of death in literature are prolific throughout his essays, such as, $O$ espaço literário and A parte do fogo.

Keywords: death, Lygia Fagundes Telles, Maurice Blanchot.

\section{Resumen}

A partir del cuento Natal na barca, de Lygia Fagundes Telles, este artículo analiza la perspectiva de la imposibilidad de la muerte en tres cuentos ("As formigas", "Anão de jardim" y "Venha ver o pôr-do-sol") y en dos novelas (Ciranda de pedra y As meninas) de la autora. En diálogo con los textos de Lygia, el escritor francés Maurice Blanchot nos ofrece la base teórica de este artículo, ya que la idea de la imposibilidad de la muerte en la literatura es tratada de profundamente en sus libros de ensayos, tales como, O espaço literário y A parte do fogo.

Palabras clave: muerte, Lygia Fagundes Telles, Maurice Blanchot.

\author{
Se eu soubesse \\ Teu nome verdadeiro \\ Te tomaria \\ Úmida, tênue \\ E então descansarias. \\ Se sussurrares \\ Teu nome secreto \\ Nos meus caminhos \\ Entre a vida e o sono \\ Te prometo, morte, \\ A vida de um poeta. A minha: \\ Palavras vivas, fogo, fonte.
}

\footnotetext{
* Doutor em literatura comparada e pós-doutorando na Universidade Federal Fluminense (UFF), Niterói, RJ, Brasil. (Dorcid.org/0000-0001-5519-3792. E-mail: davi_a_pimentel@yahoo.com.br
} 


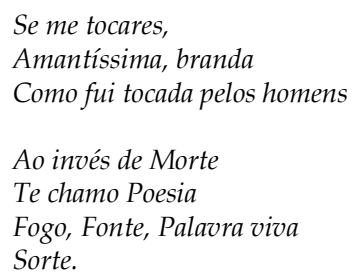

Hilda Hilst. Da morte. Odes mínimas.

\section{Prólogo: a barca da morte}

São quatro os personagens-passageiros que, dentro de uma barca desprovida de qualquer ornamento e despida de toda e qualquer beleza, atravessam um rio esverdeado, semelhante a um pântano por seu caráter frio e lodoso que adquire nas trevas da noite. Nessa embarcação "desconfortável, tosca" (Telles, 1998, p. 105), a narradora-passageira do conto "Natal na barca", de Lygia Fagundes Telles, divide o espaço-barca com um velho bêbado, uma mulher e uma criança - o bilheteiro da barca está presente, embora a sua presença se dê através de sua ausência, permitindo aos quatro passageiros desfrutar de uma solidão compartilhada e, por vezes, desejada: "E o melhor ainda era não fazer nada, não dizer nada, apenas olhar o sulco negro que a embarcação ia fazendo no rio" (Telles, 1998, p. 105). A barca segue seu curso como se estivesse, na verdade, em suspensão, como se o rio fosse uma longa trama líquida que apenas mantivesse a embarcação em movimento aparente, não há uma realidade do movimento, mas uma pausa-movente que dá aos passageiros e ao leitor uma sensação de deslocamento que não existe de fato pois todos, personagens, narradora, embarcação, escrita, estão embalados pela morte, ou melhor, pelo espectro da morte que tudo envolve e ameaça: "Debrucei-me na grade de madeira carcomida. Acendi um cigarro. Ali estávamos os quatro, silenciosos como mortos num antigo barco de mortos deslizando na escuridão. Contudo, estávamos vivos. E era Natal" (Telles, 1998, p. 105). O estar vivo é a certeza que a narrativa deixa em suspenso.

$\mathrm{O}$ viver e o morrer estão separados por um fio tênue que a qualquer momento pode ser cortado por uma Parca e tudo volta a ser apenas morte, escuridão. Na leitura do conto de Lygia, a vida está em suspensão pois, nele, a morte tudo consome, abraça, como a mãe que abraça o filho quase-morto: "Era uma mulher jovem e pálida. O longo manto escuro que lhe cobria a cabeça dava-lhe o aspecto de uma figura antiga" (Telles, 1998, p. 105). A morte se faz presente em muitas passagens do conto, principalmente na estrutura da barca, que, por sua vez, é a própria estrutura da narrativa de Lygia: a morte está na palavra, devora-a e permite-lhe a vida no espaço literário. A vida da palavra, como veremos a seguir, somente é possível através de sua própria morte. De modo semelhante à barca de Caronte, o barqueiro mítico que conduzia as almas dos recém-mortos pelos pântanos do Aqueronte, a barca de Lygia conduz os seus personagens-passageiros, através de sua escrita-para-a-morte, à ideia da morte impossível no espaço literário: "Deixei cair o xale novamente e voltei-me para o rio. O menino estava morto. Entrelacei as mãos para dominar o tremor que me sacudiu. Estava morto. A mãe continuava a niná-lo, apertando-o contra o peito. Mas ele estava morto" (Telles, 1998, p. 109). É preciso lembrar que estamos, enquanto leitores, nesta mesma barca... a barca da morte.

\section{A morte para Blanchot}

O curto - e inquietante - texto de "Natal na barca", presente no livro Mistérios, de Lygia Fagundes Telles, nos distancia do pensamento da morte habitualmente compartilhado socialmente: a morte enquanto fim, objetividade, certeza e verdade. Em Lygia, a morte adquire uma outra característica: a impossibilidade. É a criança morta de fato nos braços da mãe que segundos depois acorda e que nos faz pensar na fragilidade do pensamento consumado sobre a morte que tanto partilhamos durante séculos. A morte, aqui, está posta em questão. Ou melhor, em Lygia, a ideia que temos da morte está posta em questão. "Natal na barca", com sua 
estrutura aparentemente sóbria, se abre para uma perspectiva da morte que se revela complexa e desnorteadora para leitores de fôlego curto. Sua arquitetura discursiva conduz o leitor ao clímax inesperado até mesmo para a própria narradora, ambos estão sozinhos na revelação da impossibilidade da morte e sozinhos permanecem quando a morte da criança presentifica as suas mortes em vida. E não por menos o encontro da narradora com a Morte se dá na noite de Natal, que representa o nascimento de Jesus, o Salvador. No entanto, talvez por ironia divina, o nascimento não se revela para a vida, mas para a morte, pois nascemos para, mais na frente, morrermos: essa é possivelmente a única verdade à qual temos acesso. O nascer se faz para o morrer, logo, o Salvador nada pôde salvar, nem a si próprio, como ficou comprovado por seu próprio Pai. Lygia nos descentra, desfaz as nossas certezas e nos arremessa a uma realidade possível enquanto pensamento possível: possibilidade que se constrói no literário.

A partir dessa possibilidade de um real ficcional no qual a morte é impossível, Lygia dialoga estreitamente com o escritor francês Maurice Blanchot, para quem a impossibilidade da morte é objeto de reflexão. No texto "A literatura e o direto à morte", do livro A parte do fogo, Blanchot nos diz que, antes do rito fúnebre e impessoal que adquiriu no curso do mundo, a morte se configura como poder, razão, estabilidade e objetivo para os homens, sejam eles civilizados ou não. A morte, entendida não mais como algo factual e pesaroso, mas como instrumento do poder e modo complexo da estabilidade do mundo, se instaura no terreno do humano como a potência modeladora do homem, atuando em sua constituição pessoal e social. A morte, diz o escritor francês, é a esperança dos homens de serem homens: "É nisso que podemos dizer que existe ser, porque existe o nada: a morte é a possibilidade do homem, é a sua chance, é por ela que nos resta o futuro de um mundo realizado; a morte é a maior esperança dos homens, sua única esperança de serem homens" (Blanchot, 1997, p. 323).

Na perspectiva blanchotiana, a morte é a possibilidade do homem se nomear homem e nomear os seres ou as coisas através da linguagem - linguagem que se desenha como a base do mundo real e da literatura. A nomeação do ser se dá através da perda do ser, na ausência que é o ato de linguagem no espaço cotidiano do homem. É a cada modulação verbal que o sopro da morte se apresenta como palavra, convertendo-se em ausência logo após ser proferida. Lembrando Giorgio Agamben, no texto "Ideia da morte", do livro Ideia da prosa, a morte é linguagem: "O anjo da morte, que em certas lendas se chama Samael, e do qual se conta que o próprio Moisés teve de o afrontar, é a linguagem" (Agamben, 1999, p. 126). Ao nos comunicarmos com o outro, ao nos apresentarmos ao outro ou ao falarmos das coisas do mundo ao outro, não é o referente da palavra que será entregue por nós, mas a ausência desse referente que está simbolicamente associado à palavra que o representa. A palavra no espaço do humano não traz o ser/a coisa que é proferido(a) por nós, mas a ausência desse ser/dessa coisa, pois a palavra cachorro, por exemplo, exige a supressão do animal ao qual fazemos referência. E nesse espaço da palavra-oca, o ouvinte irá preenchê-la, à nossa revelia, com um cachorro qualquer, um cachorro plural, diversificado, totalmente diferente daquele que tínhamos em mente. É no diálogo da supressão que a morte detém a linguagem e faz dela a sua própria linguagem: "A palavra me dá o que ela significa, mas primeiro o suprime" (Blanchot, 1997, p. 310).

Há, assim, uma sucessão de mortes no momento em que dialogamos com o nosso interlocutor: a morte do ser para dar lugar ao referente, a morte do referente para dar lugar à palavra e a morte da palavra para que surja a ideia ou o significado que ela traria em sua estrutura desde já esvaziada. A partir dessa perspectiva, a morte se torna necessária ao homem, pois, sem a possibilidade da morte, não haveria o desenvolvimento da linguagem, logo, não haveria a organicidade do mundo e muito menos a literatura. Ao permitir o progresso da linguagem, a morte permitirá também a reflexão sobre si mesma, sobre a sua existência no terreno do humano. O homem, entretanto, proporá entendê-la não como a base da linguagem, mas como acontecimento, como causa, como lugar desconhecido, como fronteira intransponível, como acesso negado, como espaço interdito. Desse modo, a morte provocará o homem de muitas maneiras, fará dele um sacerdote para entendê-la, fará dele um mago na elaboração de poções do retardo da velhice, ludibriá-lo-á com mapas da fonte da juventude, 
fará dele um filósofo para interpretar o morrer ou fará dele um místico para que com a palavra do(s) deus(es) acalme os homens temerosos:

- A senhora não acredita em Deus?

- Acredito - murmurei.

E ao ouvir o som débil da minha afirmativa, sem saber por quê, perturbei-me. Agora entendia. Aí estava o segredo daquela segurança, daquela calma. Era a tal fé que removia montanhas... (Telles, 1998, p. 108).

Porém, somente poderemos nos aproximar do espaço - interdito - da morte quando passarmos a compreendê-la enquanto esteio, arrimo e alicerce da linguagem:

Mas não temos nada a supor: sobre esse sentido do sentido das palavras, que tanto é o movimento da palavra para a sua verdade quanto o seu retorno, pela realidade da linguagem, ao fundo obscuro da existência, sobre essa ausência pela qual a coisa é aniquilada, destruída, para se tornar ser e ideia, nós nos interrogamos longamente. Ela é essa vida que carrega a morte e nela se mantém, a morte, o poder prodigioso do negativo, ou ainda a liberdade, pelo trabalho de quem a existência é destacada dela mesma e tornada significativa (Blanchot, 1997, p. 329-30, grifo do autor).

\section{Há formigas na barca}

A linguagem deriva da morte das palavras. E essa morte é o fôlego presente na vida dessas palavras. Todavia, na literatura, a morte se pluraliza, torna-se ambígua, pois, ao mesmo tempo em que torna possível o discurso ficcional, ela se ausenta enquanto impossibilidade: a presença-ausência da morte. No conto "Natal na barca", a narradora - ao se deparar com a possível imagem do menino-moribundo embalado pelos braços de sua mãe-morte de feições pálidas e antigas - se encontra em uma fronteira que a aterroriza: ela está entre a vida e a morte. Ou melhor, diante da vida-morte, pois a mãe ainda continua a embalar a criança como se nada a levasse a crer em sua morte. É nesse momento da narrativa que um corte é feito: o limite entre o espaço dos vivos e dos mortos é anulado e um novo espaço se manifesta, o da impossibilidade da morte: "- Acordou o dorminhoco! E olha aí, deve estar agora sem nenhuma febre. / - Acordou?! / Ela sorriu: / - Veja..." (Telles, 1998, p. 109). O que aterroriza a narradora de Lygia é exatamente a perda da certeza da morte e a prefiguração de sua impossibilidade, o que a leva a uma reflexão mais aprofundada de sua existência enquanto ser vivo-porém-morto: o morrer da criança se configura também como o morrer em vida da própria narradora. O estar vivo somente pode ser possível uma vez que se está morto. Vivemos para a morte: máxima irrevogável. Jacques Derrida, em Demeure, ao analisar uma narrativa curta de Blanchot, intitulada L'instant de ma mort, na qual a impossibilidade da morte se manifesta de modo dialogável com o que ocorre no conto de Lygia, escreve: "Ela vai vir, a morte, existe uma prorrogação, um último prazo suspenso, uma parada da pena de morte. Mas o que vai vir, o que está em vias de vir sobre mim, eis o que terá já tido lugar: a morte já teve lugar" (Derrida, 1998, p. 60, tradução nossa). A morte já se encontra em nossas vidas: é o que nos permite falar e viver. A morte somos nós.

Essa revelação atordoante faz com que a narradora busque fugir do horror instaurado na barca pelas figuras-mensageiras, mãe e filho, que anunciam aos passageiros, mas principalmente à narradora do conto, a verdade da vida, que só pode ser vivida tendo a consciência da morte, que, por sua vez, é a morte impossível, pois nada nos dá a certeza de que o espaço do morrer seja o espaço da anulação total do ser vivo: estamos vivos para sempre mortos ou mortos para sempre vivos. Quando mortos ainda estamos vivos, mas em outro espaço - esse ainda interdito ao homem, no que se refere a pensar o espaço propriamente da morte: o outro lado do abismo. Na esteira da impossibilidade da morte na literatura, "As formigas", narrativa de Lygia também presente em Mistérios, dialoga de modo espelhado com o texto "Natal na barca". Os dois contos têm início na noite, algo que se revelará mais à frente está ocultado pelas trevas noturnas, tudo e todos estão como que em 
suspensão, sabem os personagens que algo excede os limites da realidade, nada está em sua ordem habitual, como reconhece a narradora de "As formigas": "Quando minha prima e eu descemos do táxi já era quase noite. Ficamos imóveis diante do velho sobrado de janelas ovaladas, iguais a dois olhos tristes, um deles vazado por uma pedrada. Descansei a mala no chão e apertei o braço da prima. /- É sinistro" (Telles, 1998, p. 31). A estrutura do sobrado que servirá de pensão às duas estudantes universitárias guarda o mesmo aspecto da barca da outra narradora de Lygia. A casa se encontra desprovida de adereços, está carcomida pelo pó e pelo tempo, velhíssima. Nela habita uma bruxa (a morte) no dizer das meninas: "A dona era uma velha balofa, de peruca mais negra do que a asa da graúna. Vestia um desbotado pijama de seda japonesa e tinha as unhas aduncas recobertas por uma crosta de esmalte vermelhoescuro descascado nas pontas encardidas" (Telles, 1998, p. 31).

A revelação da impossibilidade da morte, que será o clímax dos dois contos, tem como lugar de performance suportes em ruínas: a barca e a casa destituídas de qualquer adorno e beleza, como se essa revelação somente pudesse vir à tona em espaços apodrecidos, corroídos, estragados, como se tudo o que se apresentasse em ordem e em contornos delimitados não pudesse carregar a singularidade de uma realidade que ultrapassa a pretensa sistematicidade estabelecida pelo homem durante a sua passagem pelo mundo. A harmonia não comportaria a desarmonia que alicerça a ideia da morte impossível, por isso a escolha desses suportes enfeados e carcomidos, nos quais os tecidos estão rasgados e reaproveitados, a madeira rachada e o chão do piso lascado: "No sofá de palhinha furada no assento, duas almofadas que pareciam ter sido feitas com os restos de um antigo vestido, os bordados salpicados de vidrilhos" (Telles, 1998, p. 31-32). Em "As formigas", diferente do que ocorre em "Natal na barca", a revelaçãoclímax é provocada a partir da imagem de um caixotinho de ossos pertencentes a um anão. Aqui, a figura da criança morta-viva cede lugar ao esqueleto de um ser morto-porém-vivo. Antes da entrada das duas hóspedes no quarto-sótão, a velha (bruxa) diz-lhes que podem ficar, caso queiram, com esse caixotinho que o antigo inquilino lá deixou. Imediatamente, uma das primas, a estudante de medicina, mostra interesse em ficar com os ossos do anão: "- De um anão? É mesmo, a gente vê que já estão formados... Mas que maravilha, é raro à beça esqueleto de anão" (Telles, 1998, p. 32). Uma raridade que as colocará frente a frente com a morte impossível.

Na noite de chegada, não mais que de repente, surge pela fresta da porta uma marcha de formigas rigorosamente enfileiradas em formação indiana, "tão apertada que nela não caberia sequer um grão de poeira" (Telles, 1998, p. 37). Elas se dirigem ao caixotinho de ossos e lá desaparecem, sem a marcha de volta. Esse evento ocorre por três noites seguidas, antes da madrugada. Quem percebe o sinistro do caso é a estudante de medicina que começa a compreender que as formigas estão montando o esqueleto do anão, estão dando ao conjunto de ossos a vida que se acreditava que eles já não mais tivessem: "Fui ver o caixotinho, todas se trançando lá dentro, lógico, mas não foi isso o que quase me fez cair pra trás, tem uma coisa mais grave: é que os ossos estão mesmo mudando de posição, eu já desconfiava mas agora estou certa, pouco a pouco eles estão... Estão se organizando" (Telles, 1998, p. 36). A montagem da estrutura óssea do anão, organizada pelas formigas, passa a sugerir à jovem estudante que a morte não seria o último estágio da vida de um ser, como aprendeu nas disciplinas do curso de medicina, mas a base da vida, que o morrer e o viver compartilham um único e mesmo espaço. A vida que se acreditou perdida se encontra viva na morte, em seus menores detalhes (formigas). Essa percepção da morte impossível presentifica, como ocorreu com a narradora de "Natal na barca", a morte em vida das duas jovens, por isso elas executam o mesmo plano de fuga da outra narradora: “- Estão mesmo montando ele. E rapidamente, entende? O esqueleto já está inteiro, só falta o fêmur. E os ossinhos da mão esquerda, fazem isso num instante. Vamos embora daqui" (Telles, 1998, p. 38).

As formigas-palavras do conto avisam às jovens aterrorizadas que a morte é, na verdade, impossível, que o viver e o morrer estão fortemente imbricados: "Vamos, vista isto, temos que sair antes que o anão fique pronto" (Telles, 1998, p. 38). E a fuga que poderia sugerir um escapar sem perdas e danos, é uma fuga sem importância, pois o grito que se escuta ao fim da narrativa 
avisa-lhes que não se pode escapar à morte, uma vez que a morte já teve lugar: "Quando encarei a casa, só a janela vazada nos via, o outro olho era penumbra" (Telles, 1998, p. 38).

\section{Sobre a morte da palavra no mundo real e na literatura}

Segundo Blanchot, a morte da palavra adquire características diferentes no espaço do mundo real e no espaço da literatura. No território do real humano, a linguagem intenta pontuar, esclarecer, notificar, sem nenhum traço de ambiguidade, o diálogo entre os homens. A morte do ser cachorro, por exemplo, não pode ser confundida com a morte do ser pássaro, não podendo haver de modo algum a permuta indiscriminada de uma palavra por outra, pois para $\mathrm{o}$ ato de comunicação é imprescindível a linguagem objetiva. A morte da palavra deve ser racionalizada, interpretada não como pluralidade, mas como intencionalidade para que não haja o temido caos - já para a literatura, o caos, nos diz Blanchot, é um elemento de grande valia, pois é a partir dele que a palavra pode executar a sua performance ambígua: "A literatura é a linguagem que se faz ambiguidade" (Blanchot, 1997, p. 327). No mundo real, é através da morte da palavra tornada elemento lógico e prático que o homem pode gerir o mundo e os demais homens: "Somente a morte me permite agarrar o que quero alcançar; nas palavras, ela é a única possibilidade de seus sentidos. Sem a morte, tudo desmoronaria no absurdo e no nada" (Blanchot, 1997, p. 312). A partir de algumas experiências de Mallarmé, Blanchot escreve um texto sobre os diferentes papéis que a linguagem adquire no mundo real e literário, o texto se intitula "Palavra bruta, palavra essencial", presente no livro O espaço literário.

Nesse texto, Blanchot nomeia de palavra bruta a linguagem utilizada pelos homens como meio para a organização do mundo, uma linguagem que serviria para a comunicação diária, na qual o significante e o significado estariam estreitamente relacionados, passando a ter um valor de uso, "porque é uma ferramenta num mundo de ferramentas onde o que fala é a utilidade, o valor de uso, nela os seres falam como valores, assumem a aparência estável de objetos existentes um por um e que se atribuem a certeza do imutável" (Blanchot, 1987, p. 33). Imutabilidade que a própria palavra rechaça, pois sabemos que a relação da palavra com o seu referente se dá através da ausência, no vazio que os abraça, na morte inútil da palavra: "Mas nada de mais estranho para a árvore do que a palavra árvore, tal como a utiliza, não obstante, a linguagem cotidiana" (Blanchot, 1987, p. 33). É por meio dessa encenação negativa que o homem estabelece o seu poder no mundo. Em contrapartida, na literatura, temos a palavra essencial que não está mais sujeita a um valor de uso ou a uma responsabilidade de clareza, nela, a morte da palavra se amplifica, torna-se plural, não-domesticada e não-objetificada: "Sob essa perspectiva, reencontramos a poesia como um potente universo de palavras cujas relações, a composição, os poderes, afirmam-se, pelo som, pela figura, pela mobilidade rítmica, num espaço unificado e soberanamente autônomo" (Blanchot, 1987, p. 35). Literatura enquanto espaço autônomo, uma vez que a relação das palavras com os seus referentes se constrói dentro de seus limites ficcionais. Ou melhor, a literatura, segundo Blanchot, não é um decalque da realidade, mas a sua própria realidade enquanto território de exclusiva autonomia.

Em outro texto, intitulado "A solidão da obra", também presente em $O$ espaço literário, Blanchot reforça ainda mais a sua interpretação da literatura como espaço autônomo: "Entretanto, a obra - a obra de arte, a obra literária - não é acabada nem inacabada: ela é. O que ela nos diz é exclusivamente isso: que é - e nada mais. Fora disso, não é nada. Quem quer fazê-la exprimir algo mais, nada encontra, descobre que ela nada exprime" (Blanchot, 1987, p. 12). Nessa perspectiva, a literatura não é um meio para, um simples instrumento de compreensão do mundo real, mas um espaço de reflexão no qual o homem é um agente atuante, onde a complexidade da vida pode ser pensada, construída, reconstruída, desconstruída, desterritorializada e reterritorializada constantemente, sempre de um modo singular e poético-performático - poético enquanto atributo, não enquanto forma. É por ser autônoma que a literatura inverte o jogo linguístico e descentra as certezas dos homens ao revelar que em cada ser vivo habita, desde sempre, a morte: "Inclinei-me. A criança abrira os olhos - aqueles olhos que eu vira cerrados tão definitivamente. E bocejava, esfregando a 
mãozinha na face corada. Fiquei olhando sem conseguir falar" (Telles, 1998, p. 110). A morte que origina a palavra é a própria morte que nos habita, uma vez que todos nós somos constituídos de linguagem, sobretudo, de linguagem: "A morte resulta no ser: essa é a esperança e essa é a tarefa do homem, pois o próprio nada ajuda a fazer o mundo, o nada é criador do mundo no homem que trabalha e compreende" (Blanchot, 1997, p. 330).

\section{Kobold}

Os anões de Lygia são um caso especial em se tratando da impossibilidade da morte na literatura. São seres que se encontram em instância, nem estão vivos, pois não possuem corpos reais, nem mortos, pois falam e pensam como se estivessem vivos. São seres mortos-porémsempre-vivos, impossíveis de morrer: "É com arrogância que agora espero a morte? Não tenho medo, não tenho o menor medo e essa é outra diferença importante entre um anão de pedra e um homem, a carne é que sofre o temor e tremor mas meu corpo é insensível, sensível é esta habitante que se chama alma" (Telles, 2004, p. 143). Em Lygia, seus anões se apresentam ora como seres de pedra, ora como seres imaginários em sonhos, ora como esqueletos que buscam dizer a vida que se camufla em seus ossos despidos de carne. São testemunhas de uma vida que se origina por meio da morte que os mantêm reféns de um corpo inútil, arenoso ou fugaz: "Imploro o inferno do corpo (e o gozo) que inferno maior eu conheci aqui empedrado" (Telles, 2004, p. 147). São observadores das ações dos outros, já que as suas próprias ações permanecem para sempre paralisadas: "Tudo somado, nesta minha vida onde não há vida (normal) o que me restou foi apenas isto, juntar as lembranças do que vi sem olhos de ver e do que ouvi sem ouvidos de ouvir" (Telles, 2004, p. 140-141). Os anões de pedra buscam o contato através do pensamento (anões filosofantes), através da palavra abafada por suas bocas carcomidas pela exposição ao sol, à chuva, aos ventos. Há, por outro lado, anões estranhamente suspeitos, como o anão que surge em "As formigas": "No sonho, um anão louro de colete xadrez e cabelo repartido no meio entrou no quarto fumando charuto. Sentou-se na cama da minha prima, cruzou as perninhas e ali ficou muito sério, vendo-a dormir" (Telles, 1998, p. 33).

Possivelmente o anão viera reclamar a posse daqueles ossos expostos no caixotinho de madeira. Ou, quem sabe, provocar as jovens ao fazê-las entender que a morte não é o fim, mas apenas o começo. A seriedade em seu olhar esconde um riso sarcástico que apenas no final do conto pode ser compreendido: "Foi o gato que miou comprido ou foi um grito?" (Telles, 1998, p. 38). O grito possível do esqueleto do anão morto-vivo ao perdê-las temporariamente de vista. Dentre todos os anões de Lygia, talvez o mais famoso seja Kobold, do conto "Anão de jardim". É dele as citações que constam no parágrafo anterior. É dele o sentimento de estar vivendo uma vida já morta, porém viva. Vida-morte ou morte-vida: cacofonia necessária quando se pensa a impossibilidade da morte. Por expressar o seu pensamento, por desafiar o seu corpo pedregoso, Kobold se revela o porta-voz dos anões de jardim dos contos e romances de Lygia. Eles estão sempre lá, como os gatos, são marcas de escrita, são marcas da autora, são palavras-anãs que ecoam a morte impossível, pois a alma, ou aquilo que os habita, não os deixa perecer, sempre os mantém vivos: "Meu peito (rachado) continua oco. A não ser um ou outro inseto (formiga) que se aventura por esta fresta, não há nada aqui dentro e contudo ouço o coração pulsante repetir e repetir EU SOU" (Telles, 2004, p. 143). As formigas - incansáveis operárias - constroem com os contos aqui destacados um pensamento elaborado sobre a impossibilidade da morte. São esses insetos que nos lembram que existe vida na morte. São elas que passeiam pelos ossos e restauram a vida que há neles. São as únicas que podem entrar na rachadura do anão de pedra e auscultar o coração inexistente que pulsa desenfreadamente: "Entraram pela fresta, bisbilhotaram o avesso da pedra e depois saíram obedecendo a mesma formação, além de disciplinada a formiga é curiosa e essa curiosidade é que a faz eterna" (Telles, 2004, p. 145). Curiosidade que a faz símbolo da morte impossível, uma vez que a formiga, como diz Kobold, é eterna.

No conto "Anão de jardim", a origem de Kobold não nos é revelada, nem mesmo a data em que foi modelado. Contudo, como os textos de Lygia conversam entre si, a genealogia de 
Kobold talvez seja a mesma dos anões de pedra que fazem uma ciranda no jardim da casa do suposto pai de Virgínia, doutor Natércio - personagens que compõem o romance Ciranda de pedra. A primeira impressão que causa a ciranda dos anões de pedra é a exclusão:

Rindo ainda, aproximou-se dos anõezinhos que dançavam numa roda tão natural e tão viva que pareciam ter sido petrificados em plena ciranda. [...] 'Quero entrar na roda também!', exclamou ela apertando as mãos entrelaçadas dos anões mais próximos. Desapontou-se com a resistência dos dedos de pedra (Telles, 2009, p. 79).

A dança em pedra dos anões ganha vida na perspectiva de Virgínia por ser, para ela, a repetição da dança em movimento dos cinco personagens que, na primeira parte do romance, a excluem de um convívio mais íntimo quando se muda para a casa daquele que ela acreditava ser seu pai, Natércio. Na concepção de Virgínia, os cinco anões são o eco dos cinco personagens que fazem de sua vida um processo de aprendizado a partir do ato excludente, são eles: Otávia e Bruna, suas irmãs, Letícia, Afonso e Conrado, seus vizinhos. Enquanto os personagens continuassem a sua dança excludente, cada vez mais a vida invadiria a estrutura em pedra dos anões: "Lentamente Virgínia voltou-se para o gramado. Agora a ciranda dos anões mergulhava na escuridão. Ali estavam os cinco de mãos dadas, Conrado, Otávia, Bruna, Afonso e Letícia" (Telles, 2009, p. 121-122).

$\mathrm{Na}$ segunda parte do romance, quando Virgínia retorna do colégio interno e deixa de lado o olhar infantil invadido por remorsos que somente o tempo poderia abrandar, a ciranda dos anões, para ela, ganha um novo significado:

Tentou vislumbrá-la. E só distinguiu os anões de pedra com as caras lívidas banhadas de luar. Agora eles se ofereciam sem reservas, de um modo ou de outro, Afonso, Bruna, Letícia e Otávia - todos agora lhe expunham as faces sem mistério. Faltava Conrado, mas naquela roda tão unida não se podia atingir um sem afetar o vizinho (Telles, 2009, p. 160).

$\mathrm{O}$ amadurecimento de Virgínia corresponde à ruína, de um modo ou de outro, da vida dos personagens que antes dançavam sua ciranda excludente: "O mal maior foi não estar nunca presente, não ver de perto as coisas que assim de longe viraram histórias de semideuses e não de seres humanos inseguros, medrosos. Teria visto tudo com simplicidade, sem sofrimento" (Telles, 2009, p. 195). O tempo não apenas corroeu os anões de pedra, como também fez certos estragos na vida daqueles que supostamente lhes davam a vitalidade do viver. Os anões morreram após desfeita a dança dos cinco personagens? Definitivamente, não. A dança continua, pois, diferentemente do que acreditávamos na primeira parte do romance, era de Virgínia que se originava a vitalidade dos anões. Era o seu olhar que revelava a vida que se ocultava na morte em pedra dos cinco anões de jardim. Os anões não eram o eco dos cinco personagens, mas o eco da vida de Virgínia, ou melhor, o eco da perspectiva de vida que tinha a personagem quando jovem. Agora, livre e madura, libertos estarão também os anões para viverem a possibilidade (impossível) de suas vidas: "Eu, que sempre fui medrosa, não sinto mais medo e isso para mim é tão extraordinário que tenho vontade de gritar de alegria. Libertei-me" (Telles, 2009, p. 199).

Os anões de Lygia são criaturas fantásticas que nunca morrem, pois a elas foi dado o direito à eternidade, como nos lembra Kobold, no conto "Anão de jardim": "Não sei, sei apenas que esta alma vai continuar não mais neste corpo rachado mas em algum outro corpo que Deus vai me destinar, Ele sabe" (Telles, 2004, p. 143-144).

\section{Morte impossível}

A presença-ausência da morte. "Natal na barca" nos conduz por terrenos completamente desconhecidos, extensões de terra que se afastam a cada aproximação da barca da morte. Somos levados, não discutimos, embora estejamos sempre atentos. Sobre a morte, o que temos são apenas conjecturas: as confissões dos moribundos não nos auxiliam na pesquisa sobre o que viria a ser a morte propriamente dita. O que esses homens-para-a-morte dizem não é ainda a morte, mas a sensação real, não mascarada, do estar a morrer. Enquanto "vivos", mascaramos a 
morte que nos habita, porém, é chegado o momento em que a Morte reclama os seus direitos: o corpo que a ela sempre pertenceu. Dessa maneira, a morte não é o que vem antes da vida, mas a própria vida. Como, então, compreendê-la dentro do espaço da vida? Como aceitá-la como parte do que nos faz viver? A morte, por outro lado, não é estágio, nem passagem, mas lugar, chão de terra batida, para onde sempre nos deslocamos: "É a primeira vez que vem por estas bandas?" (Telles, 1998, p. 106), diz a mãe-morte para a narradora de Lygia. O lugar da morte as bandas para onde conduz a barca-palavra - onde o viver e o morrer se trançam como as formigas dentro do caixotinho de madeira. É nesse lugar - não registrado em mapas - que a narradora trava um diálogo impossível com a Morte: "Já tomei esta barca não sei quantas vezes, mas não esperava que justamente hoje..." (Telles, 1998, p. 106). As reticências são a marca do diálogo em ruína, pois inacabado, impossível: "Fiquei olhando sem conseguir falar" (Telles, 1998, p. 110). Diálogo da ordem da impossibilidade: "Levantei-me. Eu queria ficar só naquela noite, sem lembranças, sem piedade" (Telles, 1998, p. 107).

\section{Ser para a morte}

Caminhamos para a morte. Essa é a certeza - talvez a única - da qual dispomos. O caminhar para a morte é próprio ao homem desde o seu nascimento. $\mathrm{O}$ fim nos aguarda desde o começo, por isso que o fim e o começo passam a ser o único caminho trilhado pelo homem ao longo de sua existência - talvez eterna. Sobre esse caminho natural que conduz o homem à morte, duas narrativas de Lygia, As meninas e "Venha ver o pôr-do-sol", cada uma à sua maneira, refazem ficcionalmente esse caminho de modo bastante significativo. Em As meninas, Ana Clara, das três amigas que moram no Pensionato Nossa Senhora de Fátima, é a única que vivencia de modo abissal esse caminhar para a morte, aliás, toda a sua vida é uma preparação para a morte. Enquanto as suas amigas vivem de maneira a não se interessar pela perspectiva do morrer que tudo envolve e abraça, Ana Clara parece estar disposta a vivenciar a morte presente em sua vida a todo momento e a todo custo: "As pupilas de Ana Clara também dilatadas mas por outros motivos, coitadinha, a droga excita a pupila com a mesma força do medo. Duas rodas pretas. Um brilho" (Telles, 2009a, p. 60). A droga age de duas diferentes maneiras na psique de Ana Clara: primeiro, como laço afetivo, é por meio da droga que a personagem se comunica com seu parceiro Max, traficante de drogas. Segundo, é através da droga que a personagem mascara a sua impotência diante da vida e os percalços extremamente dolorosos pelos quais passou na infância.

A droga age como salvação, porém, a cada trago, a cada aspiração, a cada injeção, um muito de Ana Clara vai se direcionando para a morte: "Estava dependurada na escada, berrando, tinham enterrado um florete no peito dela, enfim podre de drogas. Loucura completa. E tão imunda. Na roupa tinha lama, carvão, umas manchas suspeitíssimas. E aquele cheiro" (Telles, 2009a, p. 250). Ana Clara é a prefiguração do ser já morto em vida. Ela literalmente nasceu para morrer. E, fato desconcertante, é quando está morta que Ana parece estar mais viva e exuberante, pois, de certo modo, a personagem completou o seu ciclo, a serpente mordeu a sua própria cauda:

Lavo a boca e vou ver como ela está ficando bonita. Ajoelhada na cabeceira da cama, Lorena está sombreando de verde a pálpebra de Ana Clara. Às vezes se afasta um pouco para ver melhor o efeito. Parece satisfeita, o pincel na mão esquerda e a caixinha na direita, é canhota. Luminosa sob a base rosada, a face me parece agora mais distante. Desinteressada. Será só impressão minha ou a meia-lua dos olhos diminuiu? Está ligeiramente encoberta, como se a névoa da noite tivesse chegado até ali. Não me lembro de tê-la visto tão bem vestida e tão bem maquilada como nesta hora. Na poltrona, as correntes de prata (Telles, 2009a, p. 269).

Em "Venha ver o pôr-do-sol", o caminhar para a morte não é trilhado pelo próprio ser, como em As meninas, mas conduzido por um segundo personagem que acelera e conscientiza a sua caminhada irrevogável para a morte. É a partir de um convite de Ricardo para ver o pôr do sol mais lindo do mundo, convite para a morte, que Raquel chega a um cemitério abandonado, onde "vivos e mortos, desertaram todos" (Telles, 1998, p. 206). Será nesse espaço abandonado, de túmulos e imagens danificados, como são, aliás, todos os suportes em que a impossibilidade da 
morte é revelada, que Raquel se encontrará com a sua própria morte - encontro orquestrado com maestria por seu ex-namorado, Ricardo: "Durante algum tempo ele ainda ouviu os gritos que se multiplicaram, semelhantes aos de um animal sendo estraçalhado. Depois, os uivos foram ficando mais remotos, abafados como se viessem das profundezas da terra" (Telles, 1998, p. 214). A falta, o ressentimento e a corrosão que se alastram por todo cemitério é o reflexo também do que perpassa sentimentalmente pela psique de Ricardo no momento em que conduz a sua amada para o inferno: "Amuada mas obediente, ela se deixava conduzir como uma criança" (Telles, 1998, p. 208). Diferente de Orfeu, que vai ao encontro de Eurídice nos infernos para salvá-la, Ricardo conduz a sua amada à catacumba-infernal de onde não poderá nunca mais sair: “- Chega, Ricardo! Você vai me pagar!... - gritou ela, estendendo os braços por entre as grades, tentando agarrá-lo. [...] Esbugalhou os olhos num espasmo e amoleceu o corpo. Foi escorregando. - Não, não..." (Telles, 1998, p. 213). Raquel se tornará amiga e confidente daqueles mortos que, em gavetas, esperavam por sua chegada - destino traçado desde o seu nascimento, que o seu rancoroso ex-namorado fez questão de acelerar.

Perdida entre os mortos, Raquel solta um "grito medonho, inumano" (Telles, 1998, p. 214), que fará eco com o grito ouvido pelas jovens estudantes universitárias de "As formigas". O grito da morte ou o grito para a morte.

\section{Epílogo}

Na literatura, a morte compartilha da ausência, do silêncio e da impossibilidade originados por sua arquitetura ficcional: "O meu primeiro [filho] morreu o ano passado. Subiu no muro, estava brincando de mágico quando de repente avisou, vou voar! E atirou-se. A queda não foi grande, o muro não era alto, mas caiu de tal jeito... Tinha pouco mais de quatro anos" (Telles, 1998, p. 106-107). Por ser linguagem, é a partir do texto literário que a morte, o seu estar no mundo, pode ser pensado, refletido, problematizado, pois a literatura, longe de estreitar o pensamento, antes de formalizar conceitos, se abre para as possibilidades, para todas elas, sem se amarrar ao mastro como fez Ulisses, "a teimosia e a prudência de Ulisses, a perfídia que lhe permitiu gozar do espetáculo das Sereias sem correr risco e sem aceitar as consequências, aquele gozo covarde, medíocre, tranquilo e comedido, como convém a um grego da decadência, que nunca mereceu ser o herói da Ilíada" (Blanchot, 2005, p. 5). Há na literatura entrega, abandono e risco, movimentos essenciais para se aproximar do lugar da morte: “- Era um menino tão alegre. Tinha verdadeira mania com mágicas. Claro que não saía nada, mas era muito engraçado... A última mágica que fez foi perfeita, vou voar! - disse abrindo os braços. E voou" (Telles, 1998, p. 107). Um voo para a morte que faz da literatura, aqui, representada pelos textos de Lygia Fagundes Telles, o espaço próprio da morte, ou melhor, de sua impossibilidade: "Duas vezes voltei-me ainda para ver o rio. E pude imaginá-lo como seria de manhã cedo: verde e quente. Verde e quente" (Telles, 1998, p. 110).

\section{Referências}

AGAMBEN, Giorgio (1999). Ideia da prosa. Tradução de João Barreto. Lisboa: Edições Cotovia.

BLANCHOT, Maurice (1987). O espaço literário. Tradução de Álvaro Cabral. Rio de Janeiro: Rocco.

BLANCHOT, Maurice (1997). A parte do fogo. Tradução de Ana Maria Scherer. Rio de Janeiro: Rocco.

BLANCHOT, Maurice (2005). O livro por vir. Tradução de Leyla Perrone-Moisés. São Paulo: Martins Fontes.

DERRIDA, Jacques (1998). Demeure: Maurice Blanchot. Paris: Galilée.

HILST, Hilda (2003). Da morte: odes mínimas. In: HILST, Hilda. Da morte: odes mínimas. São Paulo: Globo.

TELLES, Lygia Fagundes (1998). As formigas. In: TELLES, Lygia Fagundes. Mistérios. Rio de Janeiro: Rocco. 
TELLES, Lygia Fagundes (1998). Natal na barca. In: TELLES, Lygia Fagundes. Mistérios. Rio de Janeiro: Rocco.

TELLES, Lygia Fagundes (1998). Venha ver o pôr-do-sol. In: TELLES, Lygia Fagundes. Mistérios. Rio de Janeiro: Rocco.

TELLES, Lygia Fagundes (2004). Anão de jardim. In: TELLES, Lygia Fagundes. Meus contos preferidos. Rio de Janeiro: Rocco.

TELLES, Lygia Fagundes (2009). Ciranda de pedra. São Paulo: Companhia das Letras.

TELLES, Lygia Fagundes (2009a). As meninas. São Paulo: Companhia das Letras. 